\title{
Making all the right moves for liaison engagement \\ A strategy for relating to faculty
}

iaison work is a relatively recent development in the history of librarianship. Liaisons began primarily as subject specialists who continued the long-standing work of mastering an area of expertise, reflected in their primary roles of collection development and reference services. But with the ever-increasing and intense pressure from university administration placed upon faculty to publish, liaison librarians have been tasked with the responsibility of supporting faculty and graduate students in their research and scholarship.

Some argue that while liaisons continue to broaden their role, they will need to remain subject specialists in the service of users, ${ }^{1}$ an attribute that is still "highly prized" by academic staff ${ }^{2}$ and by faculty. ${ }^{3}$ In fact, some academic libraries continue to interchange the job titles "subject librarian" with "liaison librarian." However, thankfully a new vision of the liaison role is now being cast, calling for "new forms of relationship building, particularly with faculty, [which] are central to effective liaison functions. New kinds of relationships are needed to respond to the changing work of faculty and researchers and to constantly evolving learning outcomes, research processes, and communication practices." ${ }^{4}$

I want to suggest a methodology for faculty engagement from the world of development called "Moves Management." G. T. "Buck" Smith, former college president and major gift fundraiser, developed the concept. Disciples of his strategy have expanded and developed his concept over the years. According to William Sturtevant, Moves Management "involves managing a series of steps (moves) with identified prospects (the 10 percent who can give 90 percent), the number and type of steps depending upon the individual involved, such that each prospect is moved from attention to interest to desire to action (AIDA) and then back to interest until he or she has given everything they will or can to your organization." ${ }^{5}$ In other words, Moves Management furnishes liaison librarians with a comprehensive strategy for relating to faculty which encourages a series of purposeful steps. This strategy seems to be exactly what some have been recently proposing. ${ }^{6}$

Using this method, every "moves manager" identifies a list of their prime donors and seeks to nurture "highly personalized" relationships with them. The main idea is to cultivate each relationship, fostering greater levels of interest and action. In order to develop these relationships, the moves manager is to:

- Develop a strategy for each prospect.

- Track each prospect's relationship with the organization.

- Plan contacts or moves for each prospect.

John G. Bales is Theology, Philosophy and Religion librarian at Baylor University-Central Libraries, email: john_g_bales@baylor.edu

(c) 2015 John G. Bales 
- Execute the plan. In other words, see that the contacts or moves are made.

- Reconfigure the strategy as things go along and refine the plan accordingly.

- Finally, coordinate the refined plan and execute the newly formulated moves. ${ }^{7}$

So how would adapting this method look for a liaison librarian? I have created a spreadsheet for the roughly 60 faculty for whom I am responsible with their name, rank, and areas of scholarly interest. I track every action step that has been taken and that is planned. There are myriad strategic steps that one can take. The point is to take each action in a way that is appropriate to the status of the relationship, that is useful to their scholarly productivity, and that builds toward the next step of engagement.

The most important benefit is that each faculty member is treated personally. This is no cookie-cutter approach. Moves Management understands that each individual faculty member has unique needs and research interests. Further, it is intended to be sensitive to the relational expectations of faculty members. There will likely be only a small group of faculty with whom the liaison will have a robust engagement. Second, the Moves Management method is strategic. Every action step has a purpose that fits into an overall plan to develop greater levels of support. The relationship is continuously cultivated for the faculty member's scholarly success. Third, plans should be customized ${ }^{8}$ according to the faculty member's needs. Liaisons should periodically measure their success and assess their plan. ${ }^{9}$ Moves Management not only allows, but encourages mid-course corrections and goal changing.

Liaisons will do more than "liaison" with faculty. They will continue to teach information literacy courses, develop collections, expertly field reference questions, and serve on various library and university committees. Liaison librarians should modify this method to accommodate their own individual job description. However, I believe our engagement with faculty will become even more pronounced in the years to come. Hence, liaison work must move from "collectionscentric to an engagement-centered model." 10 It must move beyond simple words to action. It must move from words on a job description to tangible evidence of our efforts.

\section{Notes}

1. T. T. Cataldo, M. R. Tennant, P. SherwillNavarro, and R. Jesano, "Subject specialization in a liaison librarian program," Journal of the Medical Library Association 94 no. 4 (2006): 446-8. Available from www.ncbi.nlm. nih.gov/pmc/articles/PMC1629419/.

2. Louise Cooke, Michael Norris, Nial Busby, Thomas Page, Ginny Franklin, Elizabeth Gadd, and Helen Young, "Evaluating the Impact of Academic Liaison Librarians on Their User Community: A Review and Case Study," New Review of Academic Librarianship 17 no. 1 (2011): 26. (Academic Search Complete, EBSCOhost.)

3. Zheng Y. L. Yang, "University Faculty's Perception of a Library Liaison Program: A Case Study," Journal of Academic Librarianship 26 no. 2 (2000): 124-28. Available at http:// www.sciencedirect.com/science/article/pii /S0099133399001494\#.

4. Karla Hahn, "Introduction: Positioning Liaison Librarians for the 21st Century." Research Library Issues: A Bimonthly Report from ARL, CNI, and SPARC, no. 265 (August, 2009): 1. Www.arl.org/resources/pubs/rli /archive/rli265.shtml. For the clearest, clarion call to 21st-century liaison work, see Anne R. Kenney, "Leveraging the Liaison Model: From Defining 21st Century Research Libraries to Implementing 21st Century Research Universities," Ithaka S+R, (2014): pp.1-11. Available at www.sr.ithaka.org/sites/default/files/file s/SR_BriefingPaper_Kenney_20140322.pdf.

5. W. T. Sturtevant, The Artful Journey: Cultivating and Soliciting the Major Gift (Chicago: Bonus Books, 1997), 55-6. For an excellent description of how this method is used by fundraisers, read chapter 6 , pages 49-69.

6. Frada Mozenter, Bridgette T. Sanders, and Jeanie M. Welch, "Restructuring a (continues on page 556) 
professor and linguist Claire Bowern (who also serves as vice president of the Endangered Language Fund), this blog provides a look at the fieldwork and research being done to preserve Australia's indigenous languages. Updates on publications, grants, and endangered language news items are often featured. Access: https:// anggarrgoon.wordpress.com/.

- Endangered Languages and Cultures. Fascinating and insightful blog covering all aspects of endangered languages and cultures, including issues in documentation, technology, language policy, and education. As the blog was started by faculty at the University of Sydney and remains connected to the Pacific and Regional Archive for Digital Sources in Endangered Cultures, a majority of the posts are focused on endangered languages in Australia and the South Pacific. Access: http://www.paradisec. org.au/blog/.

\section{- Indigenous Languages and Technol-} ogy (ILAT). Electronic list that focuses on issues relating to the intersection(s) of technology and language revitalization. Access: http:// www.u.arizona.edu/ cashcash/ILAT.html.

- The Linguist List. The Linguist List is a major online forum, started in 1990, that focuses on the worldwide linguistics community. Information about conferences, publications, jobs, and other resources from around the world is posted frequently. Use the site's search function to find content related to endangered languages. Access: http://linguistlist.org/.

\section{Notes}

1. http://www.nytimes.com/1981/04/05/ movies/fellini-on-men-women-love-life-artand-his-new-movie.html.

2. http://www.unesco.org/new/en/culture/themes/endangered-languages/. $\boldsymbol{n}$

"Making all the right moves ..." (continues from page 551)

Liaison Program in an Academic Library," College \& Research Libraries 61 no. 5 (2000): 439. See http://crl.acrl.org/content/61/5/432. full.pdf+html. "In summation, an effective liaison program should be comprehensive, yet detailed. It should be structured, yet provide room for flexibility. It should be well grounded in theory, yet based on proven experience."

7. Sturtevant, The Artful Journey, 55. I have slightly modified this list.

8. M. R. Tennant, L. C. Butson, M. E. Rezeau, P. J. Tucker, M. E. Boyle, and G. Clayton, "Customizing for Clients: Developing a Library Liaison Program from Need to Plan," Bulletin of the Medical Library Association 89 no. 1 (2001): 8-20, www.ncbi.nlm.nih.gov /pmc/articles/PMC31699/?tool=pmcentrez. Accessed December 1, 2014. A good reminder to tailor the plan, but does not include a useful methodology for faculty relationships.

9. Kenney proposes "focusing on outputs," ". . . but ultimately we need to shift from measuring how many departmental meetings one attends to how well integrated the liaison is in the life of the department." "Leveraging the Liaison Model." Ithaka S+R, 2014, 9.
10. Ibid., 3. n

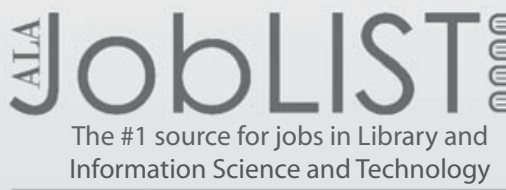

\section{JOB SEEKERS}

Refine your search-easier advanced search options. Filter and sort hundreds of job ads.

Create customized job alerts on the fly.

\section{EMPLOYERS}

Strengthen your candidate pool-

ALA reaches the most engaged

professionals and students

Simplify recruitment-flat-rate pricing, multi-ad packages, optional enhanced postings for increased visibility.
ALA HRDR ACRL

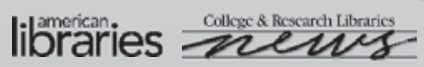 joblist.ala.org 